\title{
Systemic Risk AND Deposit INSURANCE PREMIUMS
}

\section{InTRODUCTION}

W hile systemic risk - the risk of wholesale failure of banks and other financial institutions - is generally considered to be the primary reason for supervision and regulation of the banking industry, almost all regulatory rules treat such risk in isolation. In particular, they do not account for the very features that create systemic risk in the first place, such as correlation among banks' investments (Acharya 2009; Acharya and Yorulmazer 2007, 2008); the large size of some banks (O'Hara and Shaw 1990), ${ }^{1}$ which leads to "fire-sale"-related pecuniary externalities; and bank interconnectedness (Allen and Gale 2000; Kahn and Santos 2005). In this paper, we aim to fill this important gap in the design of regulatory tools by providing a normative analysis of how deposit insurance premiums could best be structured to account for systemic risk.

Demand deposits are explicitly or implicitly insured in most countries up to some threshold amount per individual (or deposit account). While regulators in some countries have realized the need to establish a deposit insurance fund only during the 2007-09 financial crisis, others have established funds much earlier. Demirgüç-Kunt, Karacaovali, and Laeven (2005) show that most countries provide deposit insurance. Furthermore, during the crisis of 2007-09, some countries,

${ }^{1}$ Only recently, the Federal Deposit Insurance Corporation (FDIC) announced a special assessment, to be collected on September 30, 2009, that will be computed based on total assets (minus “tier 1" capital). See http:// www.fdic.gov/deposit/insurance/assessments/proposed.html. including developed countries such as Australia and New Zealand, introduced guarantees for the first time, whereas a significant majority of others increased their insurance coverage. In most cases, the capital in these deposit insurance funds is the reserve built up over time through the collection of insurance premiums from banks that receive the benefits of deposit insurance. Yet how should such premiums be charged?

We argue that the extent of systemic risk in the financial sector is a key determinant of efficient deposit insurance premiums. The basic argument is as follows. When a bank with insured deposits fails, the deposit insurance fund takes over the bank and sells it as a going concern or piecemeal. During periods of widespread bank failure, it is difficult to sell failed banks at attractive prices because other banks are also experiencing financial constraints (Shleifer and Vishny 1992; Allen and Gale 1994). Hence, in a systemic crisis, the deposit insurance fund suffers from low recovery from the liquidation of failed banks' assets. This, in turn, leads to higher drawdowns per dollar of insured deposits. This argument gives our first result: the actuarially fair deposit insurance premium - the premium that exactly covers the expected cost to the deposit insurance provider-should not only increase in relation to individual bank failure risk but also in relation to joint bank failure risk. $^{2}$

${ }^{2}$ Pennacchi (2006) shows that if insurance premiums are set to a bank's expected losses and fail to include a systematic risk premium, banks that make investments with higher systematic risk enjoy a greater financing subsidy relative to banks that make investments with lower systematic risk.

The authors thank Douglas Gale, Kenneth Garbade, Todd Keister, George Pennacchi, Asani Sarkar, Ingo Walter, and Michelle Zemel for helpful suggestions. The views expressed are those of the authors and do not necessarily reflect the position of the Federal Reserve Bank of New York or the Federal Reserve System. 
In addition, the failures of large banks lead to greater firesale discounts. This occurrence has the potential to generate a significant pecuniary externality that can have adverse contagion-style effects on other banks and the real economy (compared with the effects stemming from the failure of smaller banks). ${ }^{3}$ Hence, the resolution of large banks is more costly for the deposit insurance regulator, directly in terms of losses from liquidating large banks and indirectly from contagion effects. This leads to our second result: the premium for large banks should be higher per dollar of insured deposit compared with that for small banks.

Furthermore, bank closure policies reflect a timeinconsistency problem (see, for example, Mailath and Mester [1994] and Acharya and Yorulmazer [2007, 2008]). In particular, regulators ex ante would like to commit to being tough on banks even when there are wholesale failures to discourage banks from ending up in that situation. However, this strategy is not credible ex post, and regulators show greater forbearance during systemic crises. While such forbearance among most regulators around the world has been a feature of the current crisis, it has a strong precedent. For example, Hoggarth, Reidhill, and Sinclair (2004) study resolution policies adopted during thirty-three international banking crises from 1977 to 2002 . They document that when faced with individual bank failures, authorities have typically sought a private sector resolution in which the losses have been passed on to existing shareholders, managers, and sometimes uninsured creditors-but not taxpayers. Still, government involvement has been an important feature of the resolution process during systemic crises: at early stages, liquidity support from central banks and blanket government guarantees have been granted, usually at a cost to the budget; bank liquidations have occurred very infrequently, and creditors have rarely suffered any losses.

Such forbearance during systemic crisis creates incentives for banks to herd and become interconnected; thus, when they fail, they do so with others-and this increases their chance of a bailout. Given this collective moral hazard, we obtain our third and final result: the incentive-efficient premium that discourages banks from excessive correlation in their investments features a higher charge for joint bank failure risk than the actuarially fair premium. In other words, from a normative standpoint, the deposit insurance premium charged to banks is increasing in systemic risk.

The remainder of our paper is organized as follows. Section 2 offers a brief history of the FDIC and deposit insurance premiums. In Section 3, we describe a model we have developed to provide normative analysis of deposit insurance

\footnotetext{
${ }^{3}$ Such effects have epitomized the current crisis—especially the failures of Lehman Brothers and (effectively) AIG, although they are not deposit-insured entities.
}

premiums. Section 4 derives the actuarially fair deposit insurance premium as a function of systemic risk separately for large and small banks. In Section 5, we consider the role of forbearance and derive the incentive-efficient deposit insurance premium-taking into account all potential costs associated with the resolution of failed banks, such as the cost of inefficient liquidations and bailouts-and compare it with the actuarially fair premium. Section 6 concludes.

\section{The FDIC and Deposit Insurance Premiums}

While the three principles used to determine efficient deposit insurance premiums apply generally, it is useful to consider them in the context of how premiums have been priced in the United States. Accordingly, we briefly discuss the Federal Deposit Insurance Corporation-the U.S. deposit insurance regulator-and the premium schemes that have been used in the United States. ${ }^{4}$

In response to the devastating effects of the Great Depression, the U.S. government established the FDIC in 1933 to insure deposits of commercial banks and prevent banking panics. The FDIC's reserves began with a $\$ 289$ million capital injection from the U.S. Treasury and the Federal Reserve in 1934. Throughout most of the FDIC's history, deposit insurance premiums have been independent of bank risk, mainly because of the difficulty assessing that risk. Between 1935 and 1990, the FDIC charged flat deposit insurance premiums at the rate of approximately 8.3 cents per $\$ 100$ of insured deposits. However, in 1950, the FDIC began to rebate some of the collected premiums. The rebates have been adjusted to target the amount of reserves in the FDIC's deposit insurance fund (DIF).

While the banking industry usually wanted deposit insurance assessments to be set at a relatively low level, the FDIC preferred that premiums be high enough for the reserves to cover future claims from bank failures. In 1980, the DIF was given a range of 1.1 percent to 1.4 percent of total insured deposits. However, as a result of a large number of bank failures during the 1980s, the DIF was depleted. Subsequently, the Financial Institutions Reform, Recovery, and Enforcement Act of 1989 mandated that the premiums be set to achieve a 1.25 percent designated reserve ratio (DRR) of reserves to total insured deposits. (Chart 1 shows total deposits insured by the FDIC; Chart 2 displays the balances of the DIF and the reserve ratio for the 1990-2008 period.)

${ }^{4}$ Our discussion is based largely on Pennacchi (2009) and Cooley (2009); also see Saunders and Cornett (2007). 
Chart 1

Total Deposits Insured by FDIC

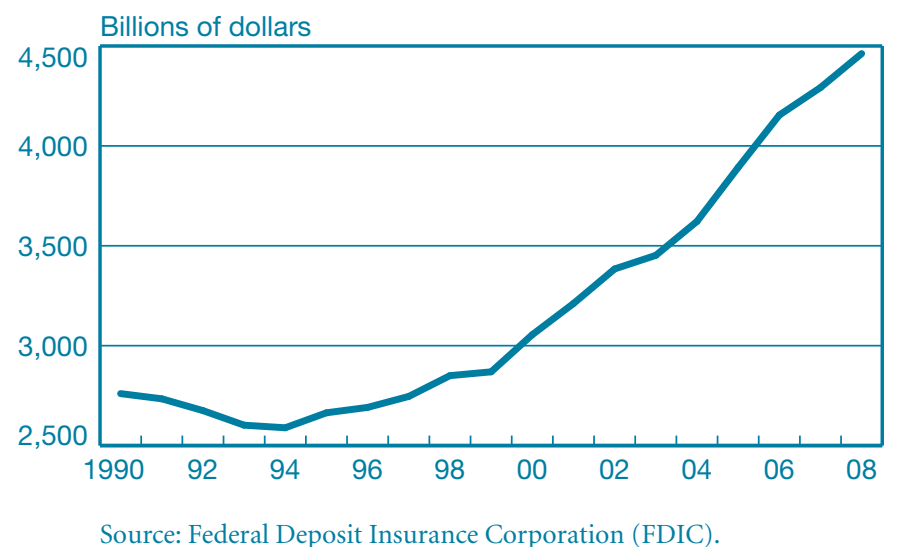

Source: Federal Deposit Insurance Corporation (FDIC).

The bank failures of the 1980s and early 1990s led to reforms in the supervision and regulation of banks; these included the Federal Deposit Insurance Corporation Improvement Act (FDICIA) of 1991, which introduced several nondiscretionary rules. In particular, the FDICIA required the FDIC to set risk-based premiums, whereby premiums differed according to three levels of bank capitalization (well capitalized, adequately capitalized, undercapitalized) and three supervisory rating groups (ratings of 1 or 2, a rating of 3 , ratings of 4 or 5 ). However, the new rules have not been as effective as possible in differentiating between banks; indeed, from 1996 to 2006, more than 90 percent of all banks were categorized in the lowest risk category (well capitalized, with a rating of 1 or 2).

Furthermore, the FDICIA and the Deposit Insurance Act of 1996 specified that if DIF reserves exceed the 1.25 percent DRR, the FDIC is prohibited from charging insurance premiums to banks in the lowest risk category. During the 1996-2006 period, DIF reserves were above 1.25 percent of insured deposits and, because the majority of banks were classified in the lowest risk category, these banks did not pay for deposit insurance.

The Federal Deposit Insurance Reform Act of 2005 brought some changes to the setting of insurance premiums. In particular, the Act gave the DRR a range of 1.15 percent to 1.50 percent, instead of a hard target of 1.25 percent. When DIF reserves exceed 1.50 percent ( 1.35 percent), 100 percent (50 percent) of the surplus is rebated to banks. If DIF reserves fall below 1.15 percent, the FDIC must restore the fund and raise premiums to a level sufficient to return reserves to the DRR range within five years.

During the financial crisis of 2007-09, DIF reserves were hard-hit. The reserves fell to 1.01 percent of insured deposits on June, 30, 2008, and they decreased by $\$ 15.7$ billion (45 percent) to $\$ 18.9$ billion in the fourth quarter of 2008 -
Chart 2

Balances of Deposit Insurance Fund and the Reserve Ratio

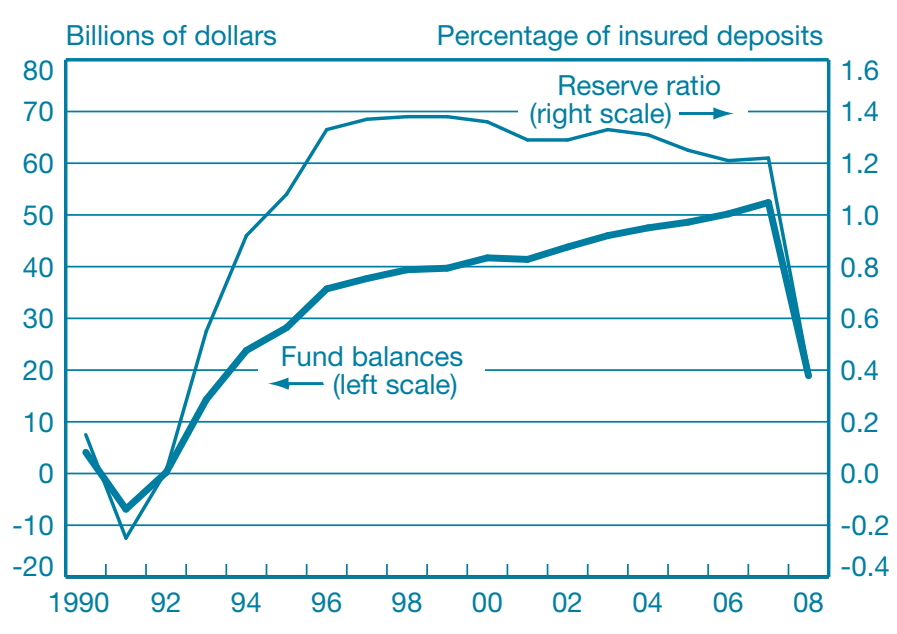

Source: Federal Deposit Insurance Corporation.

plunging the reserve ratio to 0.4 percent of insured deposits, its lowest level since June 30, 1993. ${ }^{5}$ In the first week of March 2009, the FDIC announced plans to charge 20 cents for every $\$ 100$ of insured domestic deposits to restore the DIF. ${ }^{6}$ On March 5, 2009, Sheila Bair, Chairperson of the FDIC, said that her agency would lower the charge to approximately 10 basis points if the FDIC's borrowing authority were increased. ${ }^{7}$ Subsequently, U.S. senators Christopher Dodd and Michael Crapo introduced a bill that would permanently raise the FDIC's borrowing authority to $\$ 100$ billion, from $\$ 30$ billion, as well as temporarily allow the agency to borrow as much as $\$ 500$ billion in consultation with the President and other regulators.

This short discussion confirms our earlier assertion that deposit insurance premiums have either been risk-insensitive or relied only on individual bank failure risk and never on systemic risk. Furthermore, even when premiums have been risk-sensitive, the focus has been on maintaining reserves at an "appropriate" level. For example, when the deposit insurance fund's reserves become sufficiently high relative to the size of insured deposits, the FDIC in effect returns premiums to banks. This type of approach to premiums is divorced from incentive properties. The rationale for charging banks a

${ }^{5}$ More recently, two additional failures have depleted the insurance fund further. On May 1, 2009, federal regulators shut down Silverton Bank, the fifth-largest bank to fail during the financial crisis of 2007-09. The FDIC estimates that the failure would cost the DIF \$1.3 billion. On May 21, 2009, federal regulators seized BankUnited FSB, at an estimated cost of $\$ 4.9$ billion to the DIF.

6 "Bair: Without Fee, Fund May Go Dry." American Banker, March 5, 2009.

7 "FDIC to Slash Special Fee." American Banker, March 6, 2009. 
premium on a continual basis according to individual and systemic risk, regardless of the deposit insurance fund's size, is that it causes banks to internalize the costs of their failures on the fund and rest of the economy. Since a systemic crisis would most likely make the fund fall short and require the use of taxpayer funds, the incentive-efficient use of excess fund reserves is a return to taxpayers rather than to insured banks.

\section{The Model}

Our model is purposely simple. It is meant to illustrate the straightforward nature of our three results on the efficient design of premiums. In practice, quantifying systemic risk can be a challenge, but recent advances on this front (see, for instance, Adrian and Brunnermeier [2008] and Acharya et al. [2009]) present the opportunity to employ them in revisions of future deposit insurance schemes.

Our paper is related to the literature on the pricing of deposit insurance (Merton 1977, 1978; Marcus and Shaked 1984; McCulloch 1985; Ronn and Verma 1986; Pennacchi 1987a; Flannery 1991), the difficulty (Chan, Greenbaum, and Thakor 1992) and nondesirability (Freixas and Rochet 1998) of pricing deposit insurance fairly, deposit insurance and the degree of government regulatory control over banks (Pennacchi 1987b), and, more closely, deposit insurance pricing in the presence of regulatory forbearance in the closing of banks (Allen and Saunders 1993; Dreyfus, Saunders, and Allen 1994). However, our paper differs importantly from the literature cited, as our main purpose is to analyze the pricing of deposit insurance in a way that accounts for systemic risk as well as important features that contribute to systemic risk, such as correlation among banks' investments; the large size of some banks, which leads to fire-sale-related pecuniary externalities; and bank interconnectedness (also see Pennacchi [2006]).

We use the set-up in Acharya and Yorulmazer (2007). We consider an economy with three dates $-t=0,1,2$, two banks Bank $A$ and Bank $B$, bank owners, depositors, outside investors, and a regulator. Each bank can borrow from a continuum of depositors of measure 1. Bank owners as well as depositors are risk-neutral, and obtain a time-additive utility $w_{t}$, where $w_{t}$ is the expected wealth at time $t$. Depositors receive a unit of endowment at $t=0$ and $t=1$. Depositors also have access to a reservation investment opportunity that gives them a utility of 1 per unit of investment. In each period, that is, at date $t=0$ and $t=1$, depositors choose to invest in this reservation opportunity or in their bank.

Deposits take the form of a simple debt contract with a maturity of one period. In particular, the promised deposit rate is not contingent on investment decisions of the bank or on realized returns. In order to keep the model simple and yet capture the fact that there are limits to equity financing, we do not consider any bank financing other than deposits.

Banks require one unit of wealth to invest in a risky technology. The risky technology can be thought of as a portfolio of loans to firms in the corporate sector. The performance of the corporate sector determines its random output at date $t+1$. We assume that all firms in the sector can either repay fully the borrowed bank loans or they default on these loans. In the case of a default, we assume for simplicity that there is no repayment.

Suppose $R$ is the promised return on a bank loan. We denote the random repayment on this loan as $\tilde{R}, \tilde{R} \in\{0, R\}$. The probability that the return from these loans is high $(R)$ in period $t$ is $\alpha_{t}$ :

$$
\tilde{R}=\left\{\begin{array}{l}
R \text { with probability } \alpha_{t} \\
0 \text { with probability } 1-\alpha_{t} .
\end{array}\right.
$$

We assume that the returns in the two periods are independent but allow the probability of high return to be different in the two periods. This helps isolate the effect of each probability on our results.

In addition to banks and depositors, there are outside investors who always have funds to purchase banking assets were these assets to be liquidated. However, outsiders do not have the skills to generate the full value from banking assets. To capture this, we assume that outsiders cannot generate $R$ in the high state but only $(R-\Delta)$. Thus, when the banking assets are liquidated to outsiders, there may be a social welfare loss due to misallocation of these assets. We revisit this point in Section 5, when we investigate whether actuarially fair deposit insurance can prevent systemic risk.

The notion that outsiders may not be able to use banking assets as efficiently as the existing bank owners is akin to the notion of asset-specificity, first introduced in the corporate finance literature by Williamson (1988) and Shleifer and Vishny (1992). In summary, this literature suggests that firms whose assets tend to be specific, that is, whose assets cannot be readily redeployed by firms outside of the industry, are likely to experience lower liquidation values because they may suffer from fire-sale discounts in cash auctions for asset sales, especially when firms within an industry simultaneously become financially or economically distressed. ${ }^{8}$ Regarding the evidence of such specificity for banks and financial institutions, James

${ }^{8}$ There is strong empirical support for this idea in the corporate finance literature, as shown, for example, by Pulvino (1998) for the airline industry and by Acharya, Bharath, and Srinivasan (2007) for the entire universe of defaulted firms in the United States from 1981 to 1999 (see also Berger, Ofek, and Swary [1996] and Stromberg [2000]). 
(1991) studies the losses from bank failures in the United States from 1985 through mid-1988 and documents that "there is significant going concern value that is preserved if the failed bank is sold to another bank (a 'live bank' transaction) but is lost if the failed bank is liquidated by the FDIC."

In addition, our model includes the presence of a regulator. The deposits are fully insured by the regulator and the regulator charges deposit insurance premiums. Since deposits are fully insured, they are riskless. Hence, the rate of return on deposits is equal to the rate of return from the storage technology, that is, the deposit rate is equal to 1 in both periods. For simplicity, we assume that banks pay the insurance premiums using their retained earnings from earlier investments before $t=0$.

If the return from the first-period investment is high, then the bank operates for one more period and makes the secondperiod investment. ${ }^{9}$ For a bank to continue operating, it needs one unit to pay old deposits and an additional one unit to undertake the second-period investment, a total of two units. Since available deposits for a bank amount to only one unit (the endowment of its depositors), if the return from the firstperiod investment is low, then the bank is in default, it is closed, and its assets are sold (we discuss bailouts and recapitalization in Section 5). ${ }^{10}$ We assume that if there is a surviving bank, then it has resources from its first-period profits to purchase the failed bank.

The possible states at date 1 are given as follows, where $S$ indicates survival and $F$ indicates failure:

$S S$ : Both banks had the high return, and they operate in the second period.

SF: Bank $A$ had the high return, while Bank $B$ had the low return. Bank $B$ is acquired by Bank $A$.

FS: This is the symmetric version of state $S F$.

FF: Both banks failed.

\subsection{Correlation of Bank Returns}

A crucial aspect of our model is that banks can choose the correlation of the returns from their investments by selecting the industries they invest in. At date 0 , banks borrow deposits and then choose the composition of loans that compose their respective portfolios. This choice determines the level of correlation between the returns from their respective

\footnotetext{
${ }^{9}$ For simplicity, we assume that the bank does not reinvest its profits from the first investment, for example, distribute them as dividends.

${ }^{10}$ In this model, the asset to be sold is the franchise value of the bank, that is, the expected future profit from the second-period investment the bank can take.
}

Joint Probability of Bank Returns

\begin{tabular}{cccccc} 
& & \multicolumn{2}{c}{ Same Industry } & \multicolumn{2}{c}{ Different Industries } \\
\cline { 3 - 6 } & & \multicolumn{2}{c}{ Bank B } & \multicolumn{2}{c}{ Bank B } \\
\cline { 3 - 6 } & & $\operatorname{High}(R)$ & $\operatorname{Low}(0)$ & $\operatorname{High}(R)$ & $\operatorname{Low}(0)$ \\
\hline \multirow{3}{*}{ Bank A } & High (R) & $\alpha_{t}$ & 0 & $\alpha_{t}^{2}$ & $\alpha_{t}\left(1-\alpha_{t}\right)$ \\
& $\operatorname{Low}(0)$ & 0 & $1-\alpha_{t}$ & $\alpha_{t}\left(1-\alpha_{t}\right)$ & $\left(1-\alpha_{t}\right)^{2}$
\end{tabular}

Source: Authors' calculations.

investments. We refer to this correlation as "interbank correlation."

Suppose there are two possible industries in which banks can invest, denoted as 1 and 2 . Bank $A(B)$ can lend to firms $A_{1}$ and $A_{2}\left(B_{1}\right.$ and $\left.B_{2}\right)$ in industries 1 and 2 , respectively. If in equilibrium banks choose to lend to firms in the same industry, specifically they either lend to $A_{1}$ and $B_{1}$, or they lend to $A_{2}$ and $B_{2}$, then their returns are assumed to be perfectly correlated.

However, if they choose different industries, then their returns are less than perfectly correlated, say, independent. When banks invest in the same industry, the correlation of banks' returns is $\rho=1$, whereas when they invest in different industries, we have $\rho=0$. This gives us the joint probability distribution of bank returns as presented in the table. Note that the individual probability of each bank succeeding or failing is constant ( $\alpha_{0}$ and $1-\alpha_{0}$, respectively), irrespective of the correlation in their returns. ${ }^{11}$

\section{Actuarially Fair Insurance WiTHOUT BAILOUTS}

In this section, we assume that the regulator sells the assets of the failed banks. (We analyze regulatory intervention in the form of recapitalization and bailouts in Section 5.)

Next, we show that the actuarially fair deposit insurance premium, the premium that is equal to the expected value of the payments from the insurance fund to the bank's depositors, depends on the correlation structure in banks' investments.

Since deposits are fully insured, the deposit rate in both periods is equal to 1 .

In state FF, both banks fail, and sale to another bank is not an option. Thus, the failed banks' assets are sold to outsiders, which can also be thought of as the liquidation of the banks'

${ }^{11}$ Our results hold as long as the probabilities of states $S S$ and FF are higher when banks invest in the same industry, rather than in different industries. 
assets. Note that the outsiders cannot generate $R$ from the banking assets but only $R-\Delta$. They are therefore willing to pay a price of at most $\underline{p}$ for the failed banks' assets where

$$
p^{F F}=\underline{p}=\alpha_{1}(R-\Delta-1) .
$$

We can think of $\underline{p}$ as the liquidation value of the bank.

In states $S F$ or FS, the surviving bank can acquire the failed bank's assets. Note that a surviving bank can generate the full value of $R$ from these assets. Thus, these assets are worth $\bar{p}$ for the surviving bank, where

$$
\bar{p}=\alpha_{1}(R-1)
$$

Note that $\bar{p}>\underline{p}$. We assume that neither the regulator nor the surviving bank has the full bargaining power for the sale of the failed banks' assets. Thus, the price, denoted as $p^{S F}$, lies between $\underline{p}$ and $\bar{p}$, that is, $p^{S F} \in(\underline{p}, \bar{p})$.

When banks invest in the same industry with probability ( $1-\alpha_{0}$ ), both banks fail and the proceeds from the sale of the failed banks' assets are equal to $p^{F F}=p$. Let $q_{s}$ be the insurance premium when banks invest in the same industry, where

$$
q_{s}=\left(1-\alpha_{0}\right)(1-\underline{p})
$$

When banks invest in different industries, with probability $\alpha_{0}\left(1-\alpha_{0}\right)$, only one bank fails and the proceeds from the sale are $p^{S F}$; with probability $\left(1-\alpha_{0}\right)^{2}$, both banks fail and the proceeds from the sale of the failed banks' assets are equal to $p^{F F}=p$. Let $q_{d}$ be the insurance premium when banks invest in different industries, where

$$
\begin{gathered}
q_{d}=\alpha_{0}\left(1-\alpha_{0}\right)\left(1-p^{S F}\right)+\left(1-\alpha_{0}\right)^{2}(1-\underline{p}) \\
=q_{s}-\alpha_{0}\left(1-\alpha_{0}\right)\left(p^{S F}-\underline{p}\right)
\end{gathered}
$$

Since the proceeds from the sale of failed banks' assets are lower when both banks fail, the loss to the insurance fund is higher when both banks fail. Thus, the actuarially fair insurance premiums should be higher when banks invest in the same industry, that is, $q_{s}>q_{d}$.

Result 1-(Correlation and actuarially fair insurance premiums): The actuarially fair insurance premium depends on the correlation between banks' returns and should be higher when banks invest in the same industry, and is given as $q_{s}=q_{d}+\alpha_{0}\left(1-\alpha_{0}\right)\left(p^{S F}-\underline{p}\right)>q_{d}$.

Next, we show that the insurance premium should depend on bank size as well. Suppose that instead of two banks of equal size, we let Bank $A$ be the large bank, with the size of depositors much larger than 1, while we keep the size of Bank $B$ at 1 .

We assume that if the regulator decides to liquidate the small bank, the large bank (or some other bank in the industry) has enough funds to purchase the small bank and can run it efficiently. Thus, assuming that all bargaining power does not lie with the regulator or the acquiring bank, when the small bank is liquidated the liquidation value is assumed to be $p_{\text {small }} \in(\underline{p}, \bar{p})$.

However, the size of Bank $A$ is large enough so that the small bank cannot acquire and run the large bank efficiently. Thus, when the large bank is liquidated, it can be purchased only by outside investors and the price per unit of the large bank's assets is $p_{b i g}=p$. Hence, the actuarially fair insurance premiums depend on the size of the bank. In particular, we obtain:

Result 2-(Size and actuarially fair insurance premiums): The actuarially fair premium per dollar of insured deposits for the large bank is higher compared with that of the small bank and

$$
q_{\text {small }}=\left(1-\alpha_{0}\right)\left(1-p_{\text {small }}\right)<\left(1-\alpha_{0}\right)(1-\underline{p})=q_{\text {big }} .
$$

So far, we have restricted the actions of the regulator to the provision of deposit insurance and the resolution of bank failures only through sales. Since the failure of large banks or many banks at the same time can result in more adverse effects on the rest of the economy, it is more likely that, in such cases, regulators show forbearance or intervene in the form of bailouts or capital injections, resulting in fiscal costs. This, in turn, strengthens our argument that size and correlation should be an important component of insurance premiums. In the next section, we analyze insurance premiums in the presence of bailouts and recapitalizations, taking into account costs associated with the resolution of failed banks, such as the costs of liquidations and bailouts.

\section{Resolution of Bank Failures and Insurance Premiums}

In this section, we first analyze the problem of resolving bank failures when the regulator can bail out and recapitalize failed banks as well as sell the failed banks to a surviving bank (if any) or to outsiders. We show that in the case of a joint failure of banks, the regulator may prefer to bail out or recapitalize failed banks ex post ("too-many-to-fail" guarantees). However, such guarantees create incentives for banks to herd and make correlated investments, which makes the joint failure statethat is, the state of systemic crisis-more likely in the first place.

Next, we derive the full-cost insurance premiums that take into account all social costs of bank failures, including costs of inefficient liquidations and bailouts, and show that these premiums should be higher than the actuarially fair insurance 
premiums derived in Section 4. Furthermore, we analyze how the regulator can use insurance premiums as a tool to minimize the occurrence of systemic crisis by preventing banks from choosing highly correlated investments. We use the term incentive-efficient full-cost insurance premiums to describe the premiums that take into account all social costs of bank failures while giving banks incentives to choose the low correlation.

\subsection{Resolution of Bank Failures}

Since there is no social welfare loss when assets remain in the banking system, the regulator has no incentive to intervene (in the form of bailouts) in states SS, SF, and FS. However, in state $F F$, the assets of failed banks can be purchased only by outside investors, resulting in misallocation costs. Hence, the regulator compares the welfare loss resulting from asset sales to outsiders with the cost of bailing out the failed banks. If it turns out that the welfare loss from inefficient liquidation is greater, then the regulator may decide to intervene in the form of bailouts and recapitalizations. The regulator's ex post decision is thus more involved in state FF, and we examine it fully. In order to analyze the regulator's decision to bail out or close failed banks, we make the following assumptions:

1) The regulator incurs a cost of $f(x)$ when it injects $x$ units of funds into the banking sector. We assume that this cost function is increasing, $f^{\prime}>0$, and for simplicity we consider a linear cost function: $f(x)=a x, a>0$. While we do not model this cost explicitly, we have in mind fiscal and opportunity costs to the regulator from providing funds with immediacy to the banking sector. Thus, if the regulator bails out only one bank (both banks), it incurs a bailout cost of $a$ ( $2 a)$.

The fiscal costs of providing funds to the banking sector with immediacy can be linked to a variety of sources, most notably: a) the distortionary effects of tax increases required to fund deposit insurance and bailouts and b) the likely effect of government deficits on the country's exchange rate, manifested in the fact that banking crises and currency crises have often occurred as "twins" in many (especially emerging market) countries. Ultimately, the fiscal cost we have in mind is one of immediacy: Government expenditures and inflows during the regular course of events are smooth, relative to the potentially rapid growth of "off-balance-sheet contingent liabilities," such as the costs of bank bailouts. ${ }^{12}$

2) If the regulator decides not to bail out a failed bank, the existing depositors are paid back through deposit insurance and the failed bank's assets are sold to outsiders. The crucial difference between bailouts and asset sales from an ex post standpoint is that proceeds from asset sales lower the fiscal cost from the immediate provision of deposit insurance, whereas bailouts produce no such proceeds. In other words, bailouts entail an opportunity cost to the regulator in fiscal terms.

Under these assumptions, the regulator's resolution policy can be characterized as follows. The regulator's objective in state $F F$ is to maximize the total expected output of the banking sector net of any bailout or liquidation costs. We denote this as $E\left(\Pi_{2}^{f f}\right)$. Thus, if both banks are closed, the regulator's objective function takes the value

$$
E\left(\Pi_{2}^{f f}\right)=2\left[\alpha_{1}(R-\Delta)-1\right]
$$

which is the liquidation value of banking assets to outsiders. This equals [ $\left.2\left(\alpha_{1} R-1\right)-2 \alpha_{1} \Delta\right]$, the difference between the banking sector output in each of the states $S S, S F$, and FS, minus the liquidation costs from closing both banks.

If both banks are bailed out, then the regulator's objective function takes the value

$$
E\left(\Pi_{2}^{f f}\right)=2\left(\alpha_{1} R-1\right)-f(2),
$$

as the bailout costs are now based on the total amount of funds, 2 , injected into the banking sector with immediacy. ${ }^{13}$

Comparing these objective-function evaluations, we obtain the following resolution policy for the regulator in state $F F$. It has the intuitive property that if liquidation costs $\left(\alpha_{1} \Delta\right)$ are sufficiently high and/or the costs of bailouts $(f()$.$) are not too$ steep, then there are "too many (banks) to fail" and the regulator prefers to rescue failed banks.

Resolution: When both banks fail (state FF), the regulator takes the following actions:

- If $\alpha_{1} \Delta \leq f(1)$, then both banks' assets are sold to outsiders.

- If $\alpha_{1} \Delta>f(1)$, then the regulator bails out both banks.

12 See, for example, the discussion of fiscal costs associated with banking collapses and bailouts in Calomiris (1998). Hoggarth, Reis, and Saporta (2002) find that the cumulative output losses have amounted to a sizable 15 percent to 20 percent of annual GDP in the banking crises of the past twenty-five years. Caprio and Klingebiel (1996) argue that the bailout of the thrift industry cost $\$ 180$ billion (3.2 percent of GDP) in the United States in the late 1980s. They also document that the estimated cost of bailouts was 16.8 percent for Spain, 6.4 percent for Sweden, and 8 percent for Finland. Honohan and Klingebiel (2000) find that countries spent 12.8 percent of their GDP to fix their banking systems, whereas Claessens, Djankov, and Klingebiel (1999) set the cost at 15 percent to 50 percent of GDP. Also see Panageas (2009) for an analysis of the optimal financing of government interventions.

${ }^{13}$ With the linear fiscal cost function $f($.$) , the regulator either bails out both$ banks or liquidates both. With a strictly convex fiscal cost function $f($.$) , there$ may be cases in which it is optimal to bail out one bank and liquidate the other, since the marginal cost of bailouts increases as more banks are bailed out. See Acharya and Yorulmazer (2007) for a discussion. 
Thus, the expected second-period profits of the bank depend on the regulator's decision:

$$
E\left(\pi_{2}^{f f}\right)=\left\{\begin{array}{l}
0 \text { if } \alpha_{1} \Delta \leq f(1) \\
\bar{p} \text { if } \alpha_{1} \Delta>f(1)
\end{array} .\right.
$$

Note that in either case, in state $F F$ there is a social welfare loss resulting from bailout or liquidation, whereas no such cost arises in states $S F$ or FS. Thus, the socially optimal outcome is achieved when the probability of state $F F$ is at a minimum, that is, when banks invest in different industries.

\subsection{Systemic Risk and Insurance Premiums}

First, we derive the full-cost insurance premiums - the premiums that take into account all social costs of bank failures including costs of liquidations and bailouts. Note that the actuarially fair insurance premiums in Section 4 take into account only the expected payments to depositors; thus, they fail to account for the social costs of bank failures, such as costs of liquidations and bailouts.

We can show that the full-cost insurance premiums $\tilde{q}_{s}$ and $\tilde{q}_{d}$ when banks invest in the same industry and in different industries, respectively, are given as:

$$
\begin{gathered}
\tilde{q}_{s}=\left(1-\alpha_{0}\right)\left[(1-\underline{p})+\min \left\{\alpha_{1} \Delta, f(1)\right\}\right]>q_{s}, \text { and } \\
\tilde{q}_{d}=\alpha_{0}\left(1-\alpha_{0}\right)\left(1-p^{S F}\right) \\
+\left(1-\alpha_{0}\right)^{2}\left[(1-\underline{p})+\min \left\{\alpha_{1} \Delta, f(1)\right\}\right]>q_{d} .
\end{gathered}
$$

We can obtain the relationship between these insurance premiums as follows:

(12) $\tilde{q}_{s}=\tilde{q}_{d}+\alpha_{0}\left(1-\alpha_{0}\right)\left[\left(p^{S F}-\underline{p}\right)+\min \left\{\alpha_{1} \Delta, f(1)\right\}\right]>\tilde{q}_{d}$.

As in the case of actuarially fair insurance premiums, the loss to the regulator through the insurance fund is higher when both banks fail. Furthermore, the joint failure state is always associated with social costs, such as costs from inefficient liquidations or bailouts, whereas these costs can be avoided in the individual failure states. Thus, the full-cost insurance premiums are higher than the actuarially fair insurance premiums, that is, $\tilde{q}_{s}>q_{s}$ and $\tilde{q}_{d}>q_{d}$. Furthermore, the wedge between the insurance premiums $\tilde{q}_{s}$ and $\tilde{q}_{d}$ is higher compared with the corresponding wedge for the actuarially fair insurance premiums, that is, $\tilde{q}_{s}-\tilde{q}_{d}>q_{s}-q_{d}$.

Next, we investigate banks' choice of correlation in their investments and find the incentive-efficient insurance premiums $\hat{q}_{s}$ and $\hat{q}_{d}$ that induce banks to choose the low correlation. Also, we combine our results with those of the previous discussion to find the incentive-efficient full-cost insurance premiums that take into account all costs associated with the resolution of failed banks while incentivizing banks to choose the low correlation.

In the first period, both banks are identical. Hence, we consider a representative bank. Formally, the objective of each bank is to choose the level of interbank correlation $\rho$ at date 0 that maximizes

$$
E\left(\pi_{1}(\rho)\right)+E\left(\pi_{2}(\rho)\right),
$$

where discounting has been ignored since it does not affect any of the results. Recall that if banks invest in different industries, then interbank correlation $\rho$ equals 0 , or else it equals 1 .

Note that when banks invest in the same industry, $\operatorname{Pr}(S F)=0$, so that

$$
E\left(\pi_{2}(1)\right)=\alpha_{0} E\left(\pi_{2}^{s s}\right)+\left(1-\alpha_{0}\right) E\left(\pi_{2}^{f f}\right)-\hat{q}_{s} .
$$

When banks invest in different industries, we obtain that

$$
\begin{aligned}
E\left(\pi_{2}(0)\right) & =\alpha_{0}^{2} E\left(\pi_{2}^{s s}\right)+\alpha_{0}\left(1-\alpha_{0}\right) E\left(\pi_{2}^{s f}\right) \\
& +\left(1-\alpha_{0}\right)^{2} E\left(\pi_{2}^{f f}\right)-\hat{q}_{d} .
\end{aligned}
$$

We know that $E\left(\pi_{2}^{s f}\right)=E\left(\pi_{2}^{s s}\right)+\left(\bar{p}-p^{S F}\right)$. Thus, we can write

$$
\begin{aligned}
E\left(\pi_{2}(0)\right) & =\alpha_{0} E\left(\pi_{2}^{s s}\right)+\alpha_{0}\left(1-\alpha_{0}\right)\left(\bar{p}-p^{S F}\right) \\
& +\left(1-\alpha_{0}\right)^{2} E\left(\pi_{2}^{f f}\right)-\hat{q}_{d},
\end{aligned}
$$

which gives us

$$
\begin{aligned}
E\left(\pi_{2}(1)\right)-E\left(\pi_{2}(0)\right) & =\alpha_{0}\left(1-\alpha_{0}\right)\left[E\left(\pi_{2}^{f f}\right)-\left(\bar{p}-p^{S F}\right)\right] \\
& +\hat{q}_{d}-\hat{q}_{s} .
\end{aligned}
$$

Hence, the only terms that affect the choice of interbank correlation are the subsidy that failed banks receive $\left(E\left(\pi_{2}^{f f}\right)\right)$ from a bailout in state $F F$, the discount the surviving bank receives in state $S F$ from acquiring the failed bank's assets, and the deposit insurance premiums $\hat{q}_{s}$ and $\hat{q}_{d}$. Therefore, for banks to choose the low correlation, the premium charged when banks invest in the same industry has to be at least:

$$
\hat{q}_{s}=\alpha_{0}\left(1-\alpha_{0}\right)\left[E\left(\pi_{2}^{f f}\right)-\left(\bar{p}-p^{S F}\right)\right]+\hat{q}_{d} .
$$

Note that when the regulator chooses to liquidate the failed bank, rather than bail it out, there is no bailout subsidy and the full-cost insurance premiums $\tilde{q}_{s}$ and $\tilde{q}_{d}$ are at the same time incentive-efficient, that is, they induce banks to choose the low correlation. However, when the regulator bails out failed banks, the subsidy from the bailout creates a wedge between the incentive-efficient premium $\hat{q}_{s}$ and the full-cost insurance premium $\tilde{q}_{s}$. Combining this with our previous result on the insurance premium, we obtain the incentive-efficient full-cost 
premiums as $\tilde{q}_{d}$ when banks invest in different industries and $\bar{q}_{s}=\max \left\{\tilde{q}_{s}, \hat{q}_{s}\right\}$ when banks invest in the same industry. When the regulator charges the premiums $\left(\bar{q}_{s}, \tilde{q}_{d}\right)$, banks choose the low correlation (incentive-efficient) and pay for the entire expected costs associated with their failure, including the costs of inefficient liquidations and bailouts. We obtain the following result:

Result 3-(Incentive-efficient full-cost premiums): The insurance premiums that induce banks to choose the low correlation and that cover all expected costs associated with bank failures are $\tilde{q}_{d}$ and $\bar{q}_{s}=\max \left\{\tilde{q}_{s}, \hat{q}_{s}\right\}$ when banks invest in different industries and the same industry, respectively. Furthermore, we obtain $\tilde{q}_{s}>q_{s}$ and $\tilde{q}_{d}>q_{d}$, and the wedge between the insurance premiums $\bar{q}_{s}$ and $\tilde{q}_{d}$ is higher compared with the corresponding wedge for the actuarially fair insurance premiums, that is, $\bar{q}_{s}-\tilde{q}_{d}>q_{s}-q_{d}$.

Note that the insurance premiums with regulatory intervention in the form of bailouts are different from the ones without such regulatory intervention. Given that the regulator may not be credible in closing banks during systemic crises, which creates incentives for banks to invest in the same industry ex ante, deposit insurance premiums may act as a tool to alleviate the time-inconsistency problem inherent in the regulator's policy.

We observe government bailouts during banking crises, more so when a crisis is systemic. Thus, banks may have private benefits from choosing correlated investments such as possible bailouts. In those cases, the actuarially fair premium (which may no longer be fair from a social welfare point of view) may not be enough to prevent banks from choosing highly correlated investments. If we believe that the social costs of bank failures (either misallocation costs due to liquidation and destruction of value, or costs of bailouts) increase in a convex fashion as the number of failures increases, then the regulator would like to prevent states in which many banks fail, that is, the regulator would like to prevent banks from being overexposed to common risk factors. In those cases, the actuarially fair premium may not prevent banks from investing in the same industry, that is, it may not prevent systemic bank failures. Thus, for the regulator to prevent systemic risk, all costs of failures should be priced in, and the premium imposed when banks invest in the same industry should be higher.

The practical design of regulatory tools to address important contributors to systemic risk, such as correlation and size, can be difficult and potentially costly from a political point of view. An alternative way to address these issues is through the use of closure rules. One possibility, as Acharya and Yorulmazer (2008) argue, is to use taxpayer funds, not to guarantee bank debt, but to make transfers to healthier institutions and enable the institutions to acquire failed banks at higher costs than they would using only private funds. Such mechanisms, however, have their limits, as larger banks emerge from crisis resolution and closure rules are generally negatively affected by time-inconsistency problems.

\section{Conclusion}

This paper has shown that the efficient setting of deposit insurance premiums would be most effective if it took into account systemic risk, which justifies the existence of such insurance in the first place. Some of the major factors that lead to systemic risk are correlation among banks' returns, bank size, and bank interconnectedness. These factors need to be explicitly and continually considered when setting deposit insurance premiums.

Our focus has been on the pricing of deposit insurance. Although the same principles apply to the design of other regulatory tools, such as capital and liquidity requirements (Acharya 2009), an interesting question is the effectiveness of different regulatory rules in addressing different sources of systemic risk. ${ }^{14}$ Systemic risk is a negative externality arising from one financial institution's failure on other institutions and the economy; it entails significant welfare costs when it materializes in the form of widespread failures. Regulation is required to maintain efficient levels of systemic risk-much like pollution is regulated through the imposition of certain taxes. However, such regulation will be effective only if it is tied to the extent of systemic risk.

${ }^{14}$ Sharpe (1978) shows that in the absence of moral hazard and information frictions, there is an isomorphism between risk-based insurance premiums and risk-related capital standards. Flannery (1991), however, shows that when there is asymmetry of information, this isomorphism no longer holds. 


\section{REFERENCES}

Acharya, V. V. 2009. "A Theory of Systemic Risk and Design of Prudential Bank Regulation.” Journal of Financial Stability 5, no. 3 (September): 224-55.

Acharya, V. V., S. T. Bharath, and A. Srinivasan. 2007. "Does IndustryWide Distress Affect Defaulted Firms? Evidence from Creditor Recoveries." Journal of Financial Economics 85, no. 3 (September): 787-821.

Acharya, V. V., L. Pedersen, T. Philippon, and M. Richardson. 2009. "Regulating Systemic Risk." In V. V. Acharya and M. Richardson, eds., Restoring Financial Stability: How to Repair a Failed System, Chapter 13. John Wiley \& Sons.

Acharya, V. V., and T. Yorulmazer. 2007. "Too-Many-To-FailAn Analysis of Time-Inconsistency in Bank Closure Policies." Journal of Financial Intermediation 16, no. 1 (January): $1-31$.

2008. "Cash-in-the-Market Pricing and Optimal Resolution of Bank Failures.” Review of Financial Studies 21, no. 6 (November): 2705-42.

Adrian, T., and M. K. Brunnermeier. 2008. "CoVar.” Federal Reserve Bank of New York Staff Reports, no. 348, September.

Allen, F., and D. Gale. 1994. "Limited Market Participation and Volatility of Asset Prices.” American Economic Review 84, no. 4 (September): 933-55.

- 2000. "Financial Contagion.” Journal of Political ECONOMY 108, no. 1 (February): 1-33.

Allen, L., and A. Saunders. 1993. "Forbearance and Valuation of Deposit Insurance as a Callable Put." Journal of Banking and Finance 17, no. 4 (June): 629-43.

Berger, P., E. Ofek, and I. Swary. 1996. "Investor Valuation of the Abandonment Option.” Journal of Financial Economics 42, no. 2 (October): 257-87.

Calomiris, C. W. 1998. "Blueprints for a Global Financial Architecture, Reform Proposals.” International Monetary Fund.

Caprio, G. Jr., and D. Klingebiel. 1996. "Bank Insolvencies: CrossCountry Experience.” World Bank Policy Research Working Paper no. 1620, July.
Chan, Y., S. I. Greenbaum, and A. V. Thakor. 1992. "Is Fairly Priced Deposit Insurance Possible?" Journal of Finance 47, no. 1 (March): 227-45.

Claessens, S., S. Djankov, and D. Klingebiel. 1999. "Financial Restructuring in East Asia: Halfway There?” World Bank Financial Sector Discussion Paper no. 3, September.

Cooley, T. F. 2009. “A Captive FDIC.” Forbes.com, April 15.

Demirgüç-Kunt, A., B. Karacaovali, and L. Laeven. 2005. "Deposit Insurance around the World: A Comprehensive Database." World Bank Policy Research Working Paper no. 3628, June.

Dreyfus, J.-F., A. Saunders, and L. Allen. 1994. "Deposit Insurance and Regulatory Forbearance: Are Caps on Insured Deposits Optimal?" Journal of Money, Credit, And Banking 26, no. 3, part 1 (August): 412-38.

Flannery, M. J. 1991. "Pricing Deposit Insurance When the Insurer Measures Bank Risk with Error.” Journal of BANKING AND Finance 15, no. 4-5 (September): 975-98.

Freixas, X., and J.-C. Rochet. 1998. "Fair Pricing of Deposit Insurance. Is It Possible? Yes. Is It Desirable? No.” Research in Economics 52, no. 3 (September): 217-32.

Hoggarth, G., J. Reidhill, and P. Sinclair. 2004. "On the Resolution of Banking Crises: Theory and Evidence.” Bank of England Working Paper no. 229.

Hoggarth, G., R. Reis, and V. Saporta. 2002. "Costs of Banking System Instability: Some Empirical Evidence.” Journal of BANKING AND Finance 26, no. 5 (May): 825-55.

Honohan, P., and D. Klingebiel. 2000. "Controlling Fiscal Costs of Bank Crises.” World Bank Policy Research Working Paper no. 2441 , September.

James, C. 1991. “The Losses Realized in Bank Failures." Journal of Finance 46, no. 4 (September): 1223-42.

Kahn, C. M., and J. A. C. Santos. 2005. "Liquidity, Payment, and Endogenous Financial Fragility.” Unpublished paper, Federal Reserve Bank of New York. 


\section{References (Continued)}

Mailath, G. J., and L. J. Mester. 1994. "A Positive Analysis of Bank Closure.” Journal of Financial Intermediation 3, no. 3 (June): 272-99.

Marcus, A. J., and I. Shaked. 1984. "The Valuation of FDIC Deposit Insurance: Empirical Estimates Using the Options Pricing Framework." Journal of Money, Credit, ANd BANking 16, no. 4, part 1 (November): 446-60.

McCulloch, J. H. 1985. "Interest-Risk-Sensitive Deposit Insurance Premia: Stable ACH Estimates.” Journal of BANKIng AND FinAnCe 9, no. 1 (March): 137-56.

Merton, R. C. 1977. “An Analytical Derivation of the Cost of Deposit Insurance and Loan Guarantees: An Application of Modern Option Pricing Theory." Journal of Banking and Finance 1, no. 1 (June): 3-11.

1978. "On the Cost of Deposit Insurance When There Are Surveillance Costs.” Journal of Business 51, no. 3 (June): 439-52.

O'Hara, M., and W. Shaw. 1990. "Deposit Insurance and Wealth Effects: The Value of Being 'Too Big to Fail.'” Journal of Finance 45, no. 5 (December): 1587-1600.

Panageas, S. 2009. “Too Big to Fail, but a Lot to Bail: Optimal Financing of Large Bailouts.” Unpublished paper, University of Chicago.

Pennacchi, G. G. 1987a. "Alternative Forms of Deposit Insurance: Pricing and Bank Incentive Issues." Journal of BANKING AND FinANCE 11, no. 2 (June): 291-312.

1987b. "A Reexamination of the Over- (or Under-) Pricing of Deposit Insurance.” Journal of Money, Credit, AND BANking 19, no. 3 (August): 340-60.
2006. "Deposit Insurance, Bank Regulation, and Financial System Risks." Journal of Monetary Economics 53, no. 1 (January): 1-30.

_. 2009. “Deposit Insurance.” Paper prepared for the AEI Conference on Private Markets and Public Insurance Programs. March.

Pulvino, T. C. 1998. "Do Asset Fire Sales Exist? An Empirical Investigation of Commercial Aircraft Sale Transactions." Journal of Finance 53, no. 3 (June): 939-78.

Ronn, E. I., and A. K. Verma. 1986. "Pricing Risk-Adjusted Deposit Insurance: An Option-Based Model.” Journal of Finance 41, no. 4 (September): 871-95.

Saunders, A., and M. M. Cornett. 2007. Financial Institutions Management: A Risk Management Approach. Irwin/McGraw-Hill.

Sharpe, W. F. 1978. "Bank Capital Adequacy, Deposit Insurance, and Security Values." Journal of Financial and Quantitative ANalysis 13, no. 4 (November): 701-18.

Shleifer, A., and R. W. Vishny. 1992. "Liquidation Values and Debt Capacity: A Market Equilibrium Approach.” Journal of FinANCE 47, no. 4 (September): 1343-66.

Stromberg, P. 2000. "Conflicts of Interest and Market Illiquidity in Bankruptcy Auctions: Theory and Tests.” Journal of Finance 55, no. 6 (December): 2641-92.

Williamson, O. E. 1988. "Corporate Finance and Corporate Governance.” Journal of Finance 43, no. 3 (July): 567-92.

The views expressed are those of the authors and do not necessarily reflect the position of the Federal Reserve Bank of New York or the Federal Reserve System. The Federal Reserve Bank of New York provides no warranty, express or implied, as to the accuracy, timeliness, completeness, merchantability, or fitness for any particular purpose of any information contained in documents produced and provided by the Federal Reserve Bank of New York in any form or manner whatsoever. 